\title{
Assessment of Food Service Quality of Chicken Republic and Mega Chicken Restaurants, Lagos, Nigeria
}

\author{
C. J. Akunne, P. O. Adeniji* \\ Department of Tourism Studies, Redeemer's University, Ede, Osun State, Nigeria \\ Email: *adenijio@run.edu.ng
}

How to cite this paper: Akunne, C.J. and Adeniji, P.O. (2021) Assessment of Food Service Quality of Chicken Republic and Mega Chicken Restaurants, Lagos, Nigeria. Food and Nutrition Sciences, 12, 602-613. https://doi.org/10.4236/fns.2021.126045

Received: December 5, 2020

Accepted: June 26, 2021

Published: June 29, 2021

Copyright ( 2021 by author(s) and Scientific Research Publishing Inc. This work is licensed under the Creative Commons Attribution International License (CC BY 4.0).

http://creativecommons.org/licenses/by/4.0/

\section{(c) (i) Open Access}

\begin{abstract}
In this project, assessment of food service quality of two restaurants in Lagos was carried out. The study assessed quality of food served in Chicken Republic compared with Mega Chicken. Three hundred (300) copies of questionnaires were administered to the customers in Chicken Republic Restaurant while two hundred (200) copies questionnaires were administered to the customer in Mega Chicken Restaurant. In order to analyze the data, simple percentage method was adopted in which the respondents responded to variables like, quality of services, quality of food, healthy food, price and value and condition of environment as factors that determine their patronage. The result of the study showed that the customers prefer Mega Chicken. It also showed that there is a relationship between the customers' satisfaction and customer patronage in a choice of restaurant. The result of the project could be of use to the intending restaurants' operators to understand the trend and determinants of customers' patronage. Recommendation is made that restaurant's operation should intensify effort for training and retraining of the staff on customer delight.
\end{abstract}

\section{Keywords}

Food Quality, Food Service, Mega Chicken, Customer Service, Chicken Republic

\section{Introduction}

Food service or catering industry defines this business as, institutions, and companies responsible for any meal prepared outside the home [1]. This industry includes restaurants, school and hospital cafeterias, hotels, catering operations and many other formats. Because food is a basic necessity of life and the increasing 
hectic lifestyle of people, food service industries enjoy a lot of customers all over the world [2].

According to the National Association, a growing trend is global cuisine with $66 \%$ of customers eating more widely in 2015 , than in 2010 . The companies that supply food service operators are called food services distributors. Food service distributors sell goods like small wares (kitchen utensils) and foods served in restaurant according to [3]. This industry is divided into two groups. Those that prepare and serve food and those that produce and distribute food equipment and services are needed by food providers [3]. The food service industry has become one of the most profitable industries in the world [4]. There is a lot of competition in the food service industry, so for such business to survive and grow, the service quality must be high and the customer satisfaction must be achieved [5].

Nutrition is the process of providing or obtaining the food necessary for health and growth. It is the process of taking in nutrients from the food you eat. These are needed for energy, maintenance of tissue and regulation of body processes: carbohydrates, fats, protein water, vitamins and minerals [1] [6]. For food to be nutritious, it has to meet same conditions which include the way the food is prepared and the way it is stored [7]. The diet of an individual is what he eats, which is largely determined by the availability, the processing and palatability of foods. A healthy diet includes preparation of food and storage methods that preserve nutrients from oxidation, heat or leasing, and that reduce risk of food borne illnesses. On the other hand, when a diet is poor, it has a negative effect on people; some researchers have these to say [8]. A poor diet may have an injurious impact on health, causing deficiency diseases such as blindness, anemia, scurvy, premature birth, still and cretinism [9]. Improper nutritional intake can also lead to health threatening conditions like obesity metabolic syndrome [10] and chronic's diseases like cardiovascular disease, diabetes and osteoporosis [11]. A poor diet can cause the wasting of kwashiorkor in acute causes, and the stunting of miasmas in chronic cases of malnutrition [12]. Because food is a basic need of life and because of the hectic lifestyle of people, many choose to visit a restaurant.

Healthy Diet: Nutrition guidelines recommend a whole plant food diet, and recommends using protein only as a condiment with meals. A National Geographic cover article from November 2005 entitled, The Secrets of Living Longer, also recommends a whole plant food diet. The article is a lifestyle survey of three populations, Sardinians Okinawa's, and Adventists, who generally display longevity and "suffer a fraction of the disease that commonly kill people in other parts of the developed world, and enjoy more healthy years of life" [13]. In summary, they offer three sets of best practices to emulate, which include eating fruits, vegetables, and whole grains. Nutrients are substances that provide energy for activity, growth, repair of body tissues and keeping the immune system healthy [14]. We have six nutrients in food: Protein, Carbohydrates, fats and oil, 
Vitamins, minerals and Water. These nutrients can be classified into two according to how they work in the body. Macronutrients: carbohydrates, protein, Fats and Oil and Micronutrients (Small Nutrients): Mineral salt and Vitamins. Water is general to all the nutrients and aids digestion of food responsible for sweat, tears and urine [15]. The above are basic nutrients required for good health. When anyone is lacking in these the body would not function well [16].

Nutrients are components in foods that an organism uses to survive and grow. Macronutrients provide the bulk energy an organism's metabolic system needs to function while micro nutrients provide the necessary cofactors for metabolism to be carried out. Both types of nutrients can be acquired from the environment, [17].

Micronutrients are used to build and repair tissues and to regulate body processes while macronutrients are converted to, and used for, energy [18]. The importance of eating the right nutrients cannot be overemphasized. For people to be healthy and function well we have to eat fresh whole foods with the right nutrients [19]. This is also supported by the George Mateljan Foundation which says, "The benefit of deriving nutrients from eating fresh whole foods which provide not only an abundance of individual's nutrients but also the variety necessary for their optimal function". For example, amino acids, biotin, calcium, chlorine, chromium, copper, fiber, flavonoids, folate, iodine, iron, magnesium, manganese, molybdenum, omega 3-fatty acids, pantothenic acid, phosphorus, potassium, carbohydrates, selenium, vitamin $A$, vitamin $B_{1}$ (Thiamin), vitamin $B_{12}$ (Cobalamin), vitamin $B_{2}$ (Riboflavin), vitamin $B_{3}$ (Niacin), vitamin $B_{6}$ (Pyridoxine), vitamin $\mathrm{E}$, vitamin $\mathrm{D}$, vitamin $\mathrm{K}$, vitamin $\mathrm{C}$ and Zinc have different functions in the body [20].

\section{Chicken Republic}

Chicken republic restaurant is a commercial food service business, the outfit is established for profit making and to achieve this purpose, service quality and customer satisfaction are of great importance [21]. The question is whether chicken republic restaurant is keeping its existing customers and gaining customers because of the satisfaction of her customers. Chicken republic restaurant was founded by DEJI AKINYANJU with over 70 outlets. He had a franchise deal with chicken liken, South Africa but quickly established his own brand chicken Republic in Nigeria with the help from family members and friends [22].

In 2009 the restaurant became International Standard Organization Certified by successfully undertaking the quality Management System [23]. Chicken Republic offers both meals and fast food. Their fast foods include burgers and rolls, meat pie, chicken pie, etc. They also serve drinks like water, minerals, and juice. They offer online delivery services with a minimum of N1000 order. The delivery fee is one hundred and fifty naira and delivered within one hour. These also accept vouchers. In Lagos, they have branches in Victoria Island, Lekki Phase 1, Ikoyi, Yaba, Marina, Ajah, Jakande round about and so on.

The founder plans to open more chicken republic stores in Nigeria and Africa 
due to the high patronage witnessed by the restaurant. He said a lot of people are eating from the restaurant and this achievement on the part of management of the business [24]. Eating establishments are a practical channel for health promotion activities because they enable health promotion to reach a larger number of people and to satisfy customers desire for information in a potentially cost-effective number [25]. Restaurant sometimes add a lot of spices and taste enhancing chemicals in their food to make the food tasty without considering the health hazards to the customers.

\section{Mega Chicken Restaurants}

Mega chicken is located in Lagos, Nigeria with three outlets: Lekki outlet, Ikeja outlet and Festac outlet. Festac outlet, Amuwo is randomly selected for this study. Festac community is an area with less population and some of them do not eat in the restaurant but cook their meals at home. A Mega Chicken restaurant is a food service company established in 2008, with different locations in Lagos and highly competitive [26]. They employ professional food experts with foods produced under most hygienic condition necessary.

Mega Chicken restaurant is first class 5-star that makes both international and local menu available for those who can afford their menu. They maintain standard and consistency since inception. Their call values are quality staff, food quality assurance, irresistible taste, first class service, hygiene among others. The dishes available are: African, fast foods, Chinese, continental, pastry, bakery, pizzeria, breakfast and the like.

Mega Chicken restaurants explore career opportunities to take both undergraduates and professionals to the next level [27] [28] [29].

Order from the three outlets includes cheese burger, special cold dishes, chicken, beef, vegetables, special dishes, soups, crispy rice soup, pastry, prawns, lobsters, rice/noodles, desert among others. The customer of this restaurant is limited to some effluents. This is the reason why only 200 copies of questionnaire were administered in Festac outlet.

\section{Materials and Methods}

\section{Research Design}

This research is designed to investigate the organoleptic features and services of the restaurants in Nigeria. In a bid to carry out an effective investigation, distribution of questionnaire was done to the customers in Chicken Republic and Mega Chicken restaurants both within Lagos metropolis with their branches all over the country.

\section{Population}

The intended population of the study is the entire major restaurants in Nigeria. There are thousands of them with millions of customers, but the population is streamlined to Chicken Republic customers (300) and Mega Chicken customers (200) in order to get the variables that determine customer patronage. This study was carried out in March-July, 2016 as student's research. 


\section{Instrument of the Study}

The major instrument in the research work is questionnaire. The questionnaire has demographic profiles of the respondents including gender, age bracket and marital status. The questionnaire also has different variables identified in the research questions like the quality of services, quality of food, price and value and conditions of the environment.

\section{Data Analysis Techniques}

Data collected were subjected to statistical analysis with the use of simple percentage and Chi-square to test the hypotheses of the study. The Chi-square test is a statistical test that was used to determine whether observed frequency was statistically and significantly different from expected frequency.

\section{Organoleptic Assessment}

The foods were assessed by the customers of the restaurants through the questionnaire. Their responses were strongly agreed, agreed, disagreed and strongly disagreed which provided quality of food and menu options. Majority of the respondents agreed with the food quality and menu options.

\section{Results}

Figure 1 shows the quality of food and menu options of the restaurants. Out of the total respondents $31.0 \%$ of the respondents that in Chicken Republic, strongly agree with the quality of food, $54 \%$ of the respondents agree, $14 \%$ disagree while less than $10.0 \%$ strongly disagree. Also, in Mega Chicken Restaurant, $56 \%$ of the respondents agree, $30.0 \%$ strongly agree, $12.0 \%$ disagree and less than $10.0 \%$ strongly disagree.

Figure 2 shows that in Chicken Republic, out of the total respondents, $27.0 \%$ were visiting the eatery everyday, $35.0 \%$ visited once a week, $19.0 \%$ respondents visited once a month while $18.5 \%$ visited the eatery occasionally. Also the results shows that in Mega Chicken, out of the total respondents, $2.2 \%$ visited the eatery everyday, $35.5 \%$ respondents' visit once a week, $26.9 \%$ once a month and $35.5 \%$ visited occasionally for quality service.

Figure 3 shows the distribution of respondents' menu options. Out of the total respondents in Chicken Republic, 30.0\% strongly agree with the restaurant's menu option, $40.0 \%$ agree, $20.0 \%$ disagree while less than $10.0 \%$ of the respondents strongly disagree. In Mega Chicken restaurant 50.0\% strongly agree with the menu options $40.0 \%$ agree, $20.0 \%$ disagree while less than $10.0 \%$ strongly disagree. More respondents strongly agree with menu option in Mega chicken restaurant than Chicken Republic Restaurant.

Figure 4 shows that in Chicken Republic, out of the total respondents, 39.5\% were very satisfied with the speed of service, $49.5 \%$ were satisfied, $9.5 \%$ were dissatisfied while $1.5 \%$ were very dissatisfied. The result also reveals that in Mega Chicken out of the total respondents, $33.3 \%$ were very satisfied with the speed of service, $60.2 \%$ were very satisfied while 6.5 were dissatisfied.

Figure 5 answered the question that sought to find out the level of attention 
given to customers by the eatery staff. From the result, it shows that in Chicken Republic, out of the total respondents, 29.0\% 1 were very satisfied with the level

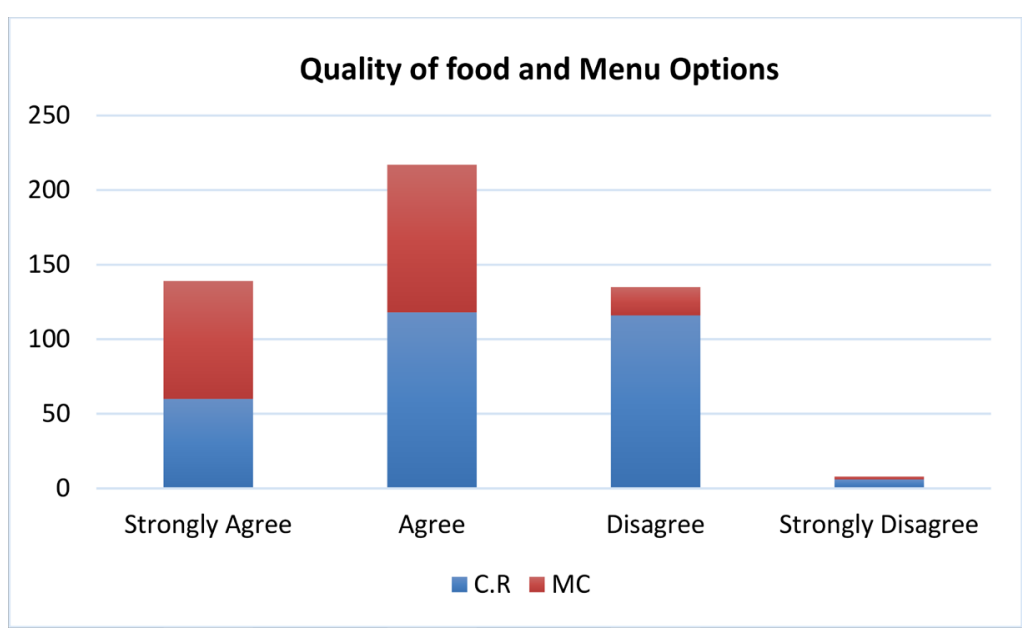

Figure 1. Quality of food and menu options.

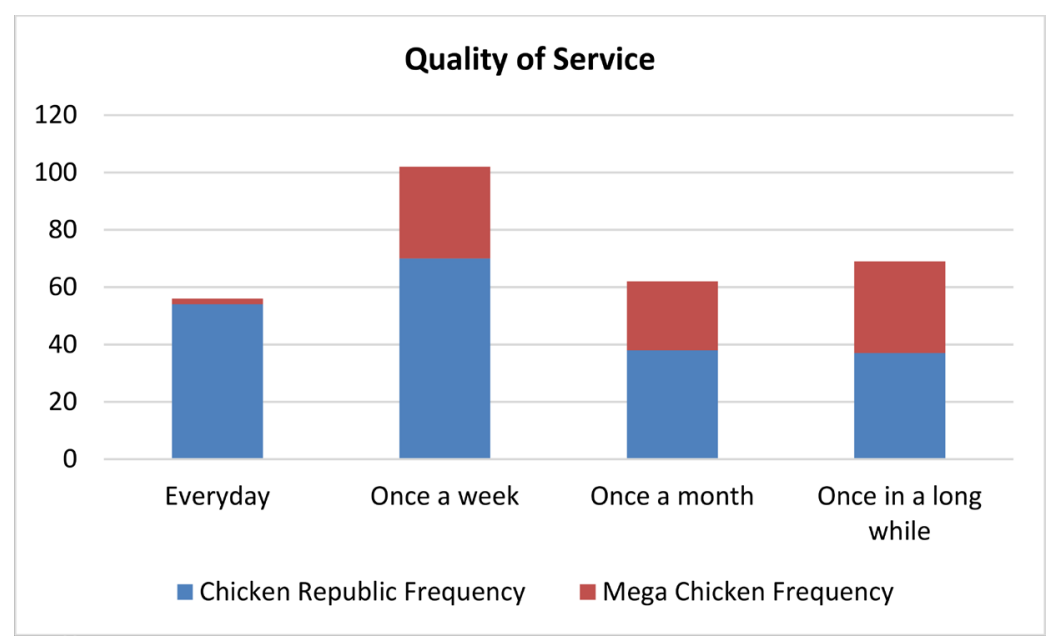

Figure 2. Quality of service.

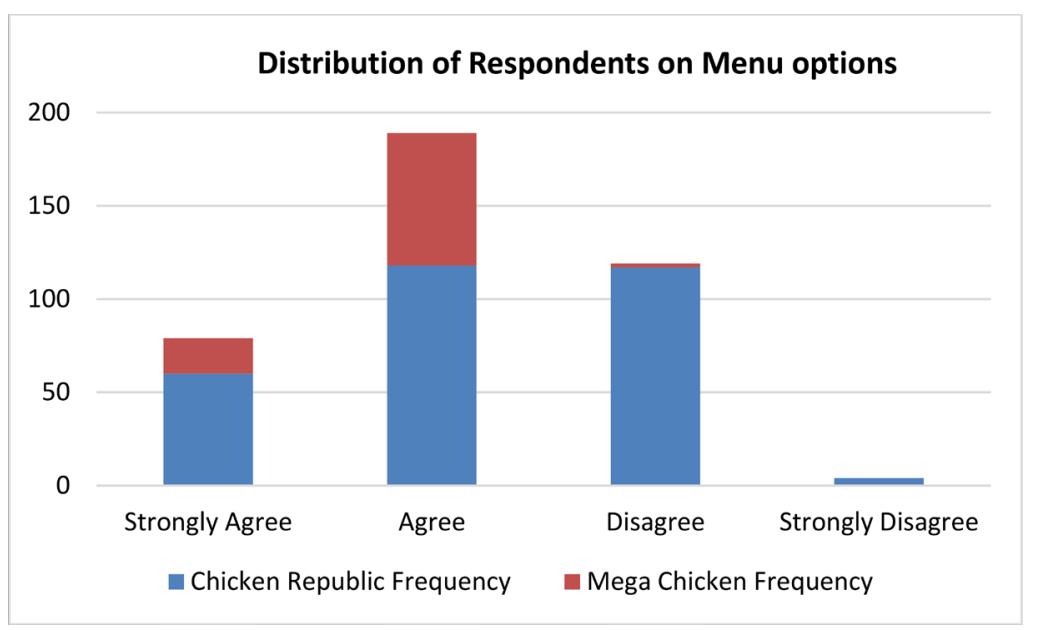

Figure 3. Distribution of respondents on menu options. 


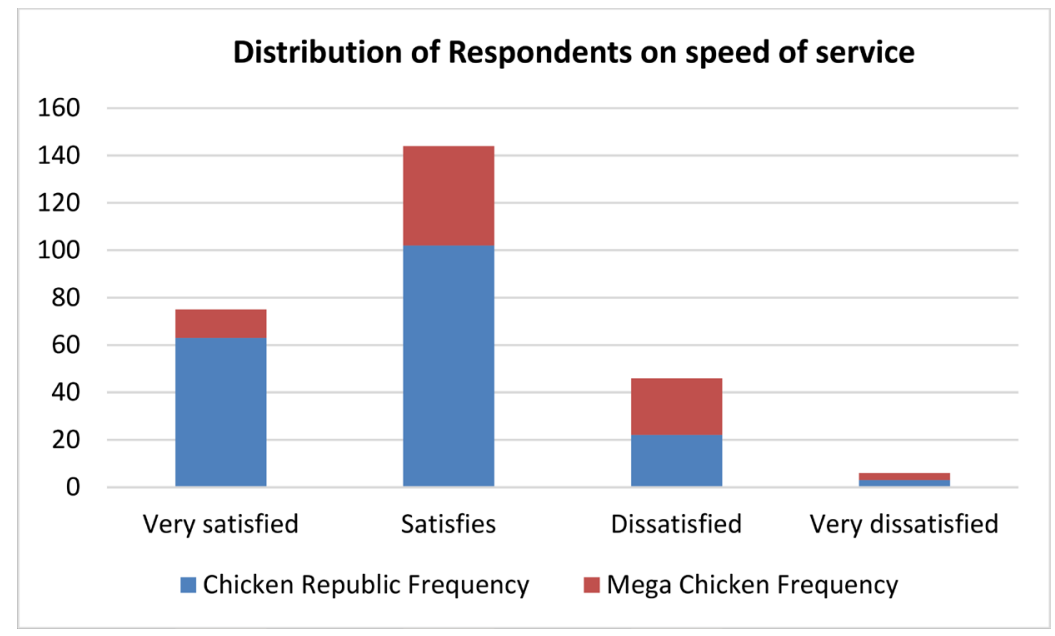

Figure 4. Distribution of respondents on speed of service.

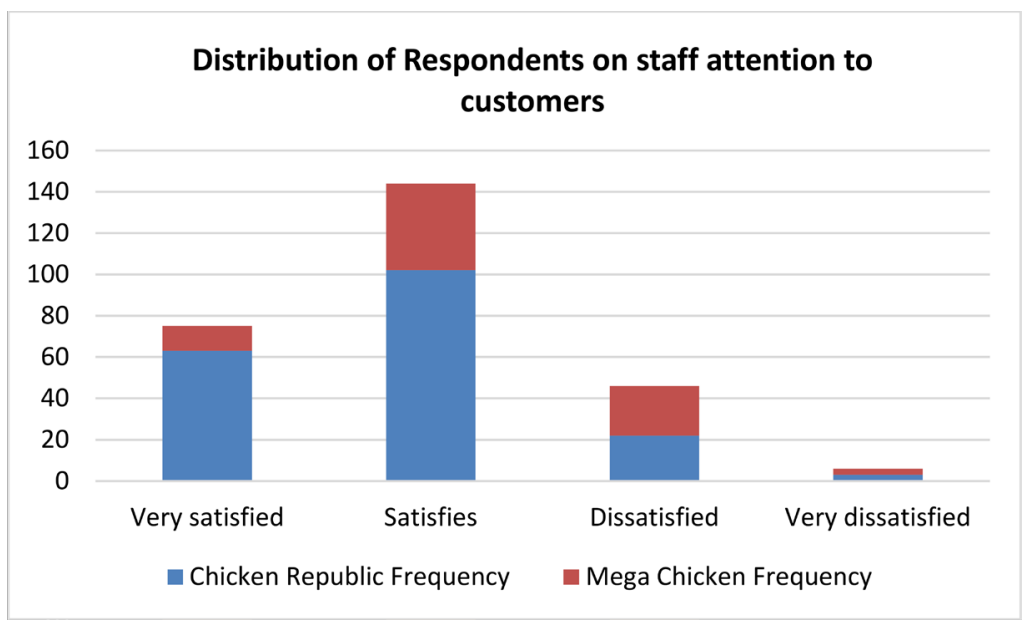

Figure 5. Distribution of respondents on staff attention to customers.

of attention given to them by the staff of the restaurant, 58.0 were satisfied, $10.0 \%$ were dissatisfied while 2.5\% were very dissatisfied. In Mega Chicken, 26.9 respondents were very satisfied with the level of attention given to them by the eatery staff, 6.5 .6 were satisfied, $6.5 \%$ were dissatisfied and $1.1 \%$ were very dissatisfied.

Figure 6 shows the results on the eateries staff neatness. In Chicken Republic, out of the total respondents, $36.0 \%$ were very satisfied with the level of neatness of the staff, $50.0 \%$ were satisfied $10.0 \%$ were dissatisfied and $2.0 \%$ were very dissatisfied. This also reveals that in Mega Chicken, out of the total respondents, $18.3 \%$ were very satisfied, $75.3 \%$ were satisfied $6.3 \%$ were dissatisfied and $1.1 \%$ were very dissatisfied.

Figure 7 shows results on the eatery staff's knowledge of food. In Chicken Republic, out of the total respondents $30.5 \%$ were very satisfied with the level of knowledge of food possessed by the staff, $51.0 \%$ were satisfied, $16.3 \%$ were dissatisfied and 2.0\% were very dissatisfied. In Mega Chicken, out of the total respondents, $16.1 \%$ were very satisfied, $74.2 \%$ were satisfied, $7.5 \%$ were dissatisfied and $1.1 \%$ were very dissatisfied. 
Figure 8 shows the results of the question that sought to find out the level of friendliness/politeness. In Chicken Republic out of the total respondents, 33.0\% were very satisfied with the level of friendliness/politeness of the eatery staff.

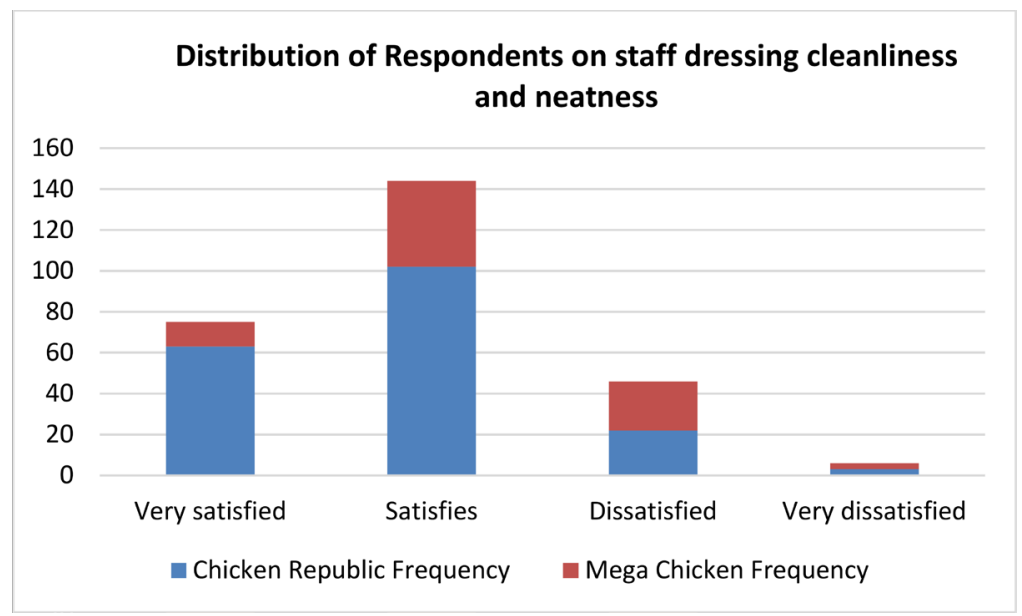

Figure 6. Distribution of respondents on staff dressing cleanliness and neatness.

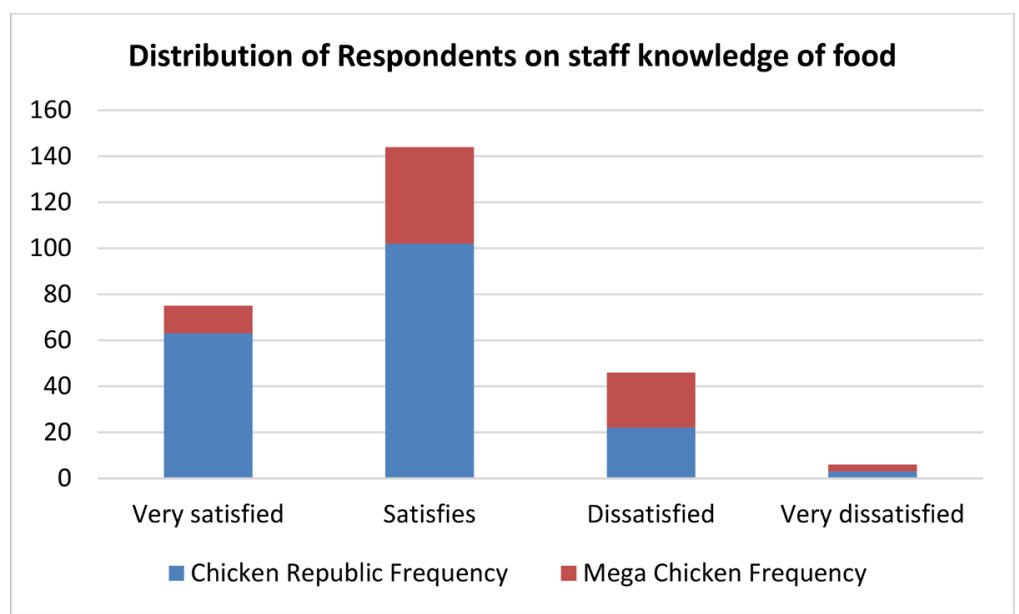

Figure 7. Distribution of respondents on staff knowledge of food.

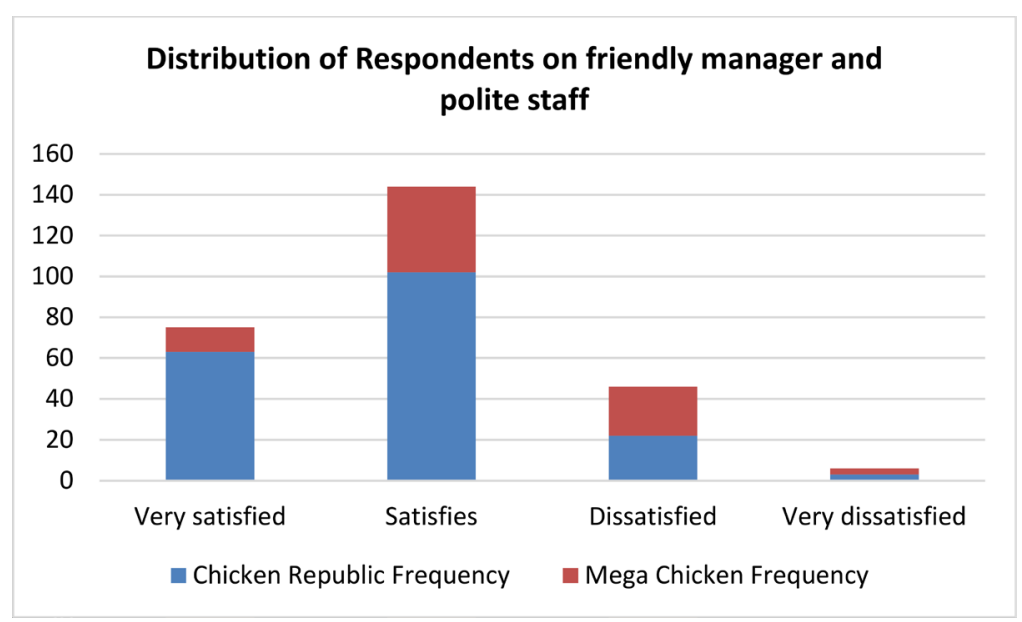

Figure 8. Distribution of respondents on friendly manager and polite staff. 
$52.0 \%$ were satisfied, $12.0 \%$ were dissatisfied and 3.0\% very dissatisfied. In Mega Chicken, out of the total respondents $14.0 \%$ were very satisfied $48.4 \%$ were satisfied, $31.2 \%$ were dissatisfied, and $6.5 \%$ were very dissatisfied.

\section{Discussion}

It was observed from this research study that the standard of Chicken Republic and Mega Chicken restaurants determines the extent of the quality of food. Mega Chicken restaurant seems to have more customers than Chicken Republic. It also seems that the costumers of Mega Chicken have more satisfaction than those of Chicken Republic [29].

There is a relationship between food quality and customers patronage. Therefore if a customer is not satisfied with the level of service in a restaurant, the customer may not patronize that restaurant again whereas a customer who is satisfied with the level of service provided by a restaurant will keep patronizing such restaurant and even bring more customers [29].

In addition, the quality of service provided by a restaurant determines the extent to which customers will patronize them. Restaurants customers especially in a developed environment have interests in the way they are being received by such restaurants. Customers are interested in the response of their request, the mode of operation, the kind of chairs they sit on, the neatness of the staff and the welcoming method of the staff [29].

Also the food quality is a determinant of the level of customer patronage in a restaurant. The taste of the food, the aroma of the food and nutritional value of the food are highly considered by the customers from the research, it could also be observed that the customer are very passionate about the price and the value of the food bought in a restaurant. Where the price and the value are correlating, customers tend to patronize such restaurant again and again. Meanwhile if the price and the value enjoyed by customers are different, the customers will switch to other restaurants where they will enjoy the value for their money [1] [6].

The research also shows that the customers are indifferent to the kind of healthy food they consume. In the research, it reveals that a restaurant that sells unhealthy food will lose most of their customers. The customers want to eat healthy food always [6] [12].

\section{Conclusions}

This study assessed the organoleptic features and services of Chicken Republic restaurant in comparism to organoleptic features and services of Mega Chicken restaurant in Nigeria.

Five (5) research questions were raised as variables which determine the level of patronage of the said restaurants. The variables are customer's satisfaction, quality of services, quality of food, price and value, and health food. The study further investigated how these factors affect the level of patronage of restaurants in Nigeria. To accomplish this, a questionnaire was printed, verified and dis- 
trusted to the customers in both Chicken Republic and Mega Chicken republic and Mega Chicken. Two hundred (200) copies of the questionnaire were given to Chicken Republic customers while one hundred (100) copies were given to Mega Chicken Restaurant in Lagos. The researcher used simple random sampling in order not to be bias in choosing the population for the study. The questions were collected and presented in a table using simple percentage method of analysis. The study shows that the customers preferred Mega Chicken Republic.

- The results also show that there is a relationship between customers' satisfaction and customer patronage in the choice of restaurant.

- The quality of food has influence on the customers' patronage in a restaurant.

- The respondents agreed that the quality of services determines the customer patronage in a restaurant.

- The study reveals that healthy food has a great influence on the customers' patronage of a restaurant.

\section{Recommendations}

Based on the findings of this study, the following recommendations are made:

- Nigeria restaurants should improve on the variables tested in this research work.

- Customer's satisfaction should be given a priority. Quality customer services or customer delight services should be improved upon.

- Also, in order to have more customers, Nigerian restaurants should consider the value and the price, before tagging a certain price to their goods.

- The quality of food should also be improved upon, because the customers are now aware of negative effects of poor food quality on their health.

- Potential restaurant owner should consider the environmental condition of the place they tend to situate their restaurants. This is because, the result of the survey shows that customers consider the environment before they enter into any restaurant.

- Lastly, restaurant owners should endeavor to organize seminar, check spelling and workshop for their staff in order to keep abreast of improved methods of rendering customer delight services.

\section{Suggestion for Further Studies}

The study should be repeated taking other restaurants as case studies. Also other variables, such as customer's income, and market structures as factors that determine customer patronage should be taken into account.

\section{Conflicts of Interest}

The authors declare no conflicts of interest regarding the publication of this paper.

\section{References}

[1] Whitney, E.N. and Rolfes, S.R. (2013) Understanding Nutrition. 13th Edition, Cen- 
gage Learning, Wadsworth, 667-670. https://www.cengagebrain.co.uk/

[2] Adeniji, P.O. (2015) Health and Living (Healthy Living) Directorate of General Studies Programme (GSP). Redeemer's University, Ede.

[3] Paswan A.K., Spears N. and Ganesh G. (2007) The Effects of Obtaining One's Preferred Service Brand on Consumer Satisfaction and Brand Loyalty. Journal of Service Marketing, 21, 75-78. https://doi.org/10.1108/08876040710737840 https://www.researchgate.net

[4] Agbor, J.M. (2011) Relationship between Customer Satisfaction and Services Quality-A Study of Three Service Sectors in Lemea. Umea School of Business, Umea University, Umeå, 1-92. https://www.diva-portal.org/smash/record/jsf

[5] Oliver, R.L. and Swan, J.E. (1989) Consumer Perceptions of Interpersonal Equity and Satisfaction in Transactions: A Field Survey Approach. Journal of Marketing, 53, 21-35. https://doi.org/10.1177\%2F002224298905300202

[6] NG, Y.N. (2005) A Study of Customer Satisfaction, Return Intention and Word of Mouth Endorsement. Master's Thesis, Oklahoma State University, Stillwater, 1-64. https://shareok.org/bitstream/handle/11244/9694/NG okstate 0664M 1503.pdf?se quence $=1$

[7] Grewal, D., Levy, M. and Kumar, V. (2009) Customer Experience Management in Retailing: An Organizational Framework. Journal of Retailing, 85, 1-14. https://doi.org/10.1016/j.jretai.2009.01.001 https://www.quadient.com/

[8] Dollah, S.N., Mansor, N. and Mohamed, M. (2012) Exploring the Major Determinants of Student Satisfaction on University Cafeteria Food Services: A Malaysian Case. Interdisciplinary Journal of Research in Business, 2, 62-67. https://www.semanticscholar.org.paper

[9] Raham, M.A. and Abdullah, M.A. (2012) Service Quality Determining an Organization Success or Failure. Kalarm Publisher, USA. https://www.researchgate.net/

[10] Wardlaw, G.M. and Kessel, M. (2002) Perspective in Nutrition. 5th Edition, McGraw Hill Publishers, New York.

[11] Liang, X. and Zhang, S. (2009) Investigation of Customer Satisfaction in Student Food Service: An Example of Student Cafeteria in NHH. International Journal of Quality and Service Sciences, 1, 113-124. https://doi.org/10.1108/17566690910945903

[12] Andaleeb, S.S. and Conway, C. (2006) Customer Satisfaction in the Restaurant Industry: An Examination of the Transaction and Specific Model. Journal of Science Marketing, 20, 3-11. https://doi.org/10.1108/08876040610646536

[13] Chang, S. and Tanin, N. (2014) Student Satisfaction with the Services Quality of Cafeteria A Structural Approach On Student Satisfaction Level With University Cafeteria. International Journal of Business, Economics and Law, 4, 105-111. http://www.researchgate.net/publication/266563244

[14] Christensen, C.M. (1993) Effect of Aroma, Flavor and Texture Judgment on Foods. Journal of Food Science, 48, 787-790. https://doi.org/10.1111/j.1365-2621.1983.tb14899.x

[15] Gibimore, M. (2012) Service Quality and Customer Satisfaction in the Restaurant Business. Central Ostrobothnia University of Applied Sciences, Kokkola, 1-51. http://www.researchgate.net

[16] Kim, H.J., Lee, C.-K., Kim, M.-J. and Ryu, K. (2011) Restaurant Healthy Food Quality, Perceived Value, and Revisit Intention: Testing a Moderating Role of Green 
Customers in South Korea. 2011 International CHRIE Conference-Refereed Track, USA, No. 5. http://scholarworks.umass.edu

[17] https://www.nationalgeographic.org/encyclopedia/nutrient/

[18] Liu, C.-H. and Tsai, W.-S. (2006) The Effect of Service Quality and Lifestyle on Consumer Choice of Channel Types. The Health Food Industry as an Example. African Journal of Business Management, 4, 1023-1039. http://www.academicjournals.org/AJBM

[19] Ndagi, J.O. (1984) Essential of Research Methodology for Nigerian Education. University Press Ltd., Ibadan, 236.

https://www.worldcat.org/title/essentials-of-research-methodology-for-nigerian-ed ucators

[20] Odediran, N.O. (2001) Essential of the Introduction Aspect of Educational Research Work for Student. A Paper Presented at the Seminar Organized by the Centre for Higher Studies, UK. https://nairametrics.com/wp-content/uploads/2013

[21] Onyene, Y.E. (2001) Research Method for Beginners: An Introducing Manual. National Open University of Nigeria, Lagos. https://lumieresolutions.com/

[22] Rahman, M.A., Kalam, A., Mohammad, H., Rahman, M.M. and Abdullah, M. (2012) The Influence of Service Quality and Price on Customer Satisfaction: An Empirical Study on Restaurant Services in Khulna Division. Research Journal of Finance and Accounting, 3, 8-16. https://www.iiste.org/Journals/index.php

[23] Sabir, R.I., Irfan, M., Akhtar, N., Pervez, M.A. and Rehman, A. (2014) Customer Satisfaction in the Restaurant Industry. Journal of Asian Business Strategy, 4, 18-31. http://www.aessweb.com/journals

[24] Sulek, K. and Hensley, R. (2014) Healthy Food Increase, the Opportunity of Consumer's Satisfaction. http://www.researchgate.net

[25] Johns, N. and Tyas, P. (1996) The Use of Service Quality Theory to Differentiate between Food Service Outlets. The Service Industry Journal, 16, 321-346. https://doi.org/10.1080/02642069600000031

[26] Kivela, J., Inbakaran, R. and Reece, J. (2000) Consumer Research in the Restaurant Environment. Part 3: Analysis, Findings and Conclusions. International Journal of Contemporary Hospitality Management, 12, 13-30. https://doi.org/10.1108/09596110010304984

[27] Hang, A. and Prybatok, N. (2009) These Attributes Are Related to Customer Satisfaction.

[28] Etutchings, D. (1994) The Food Product Chosen for Display and Space by Caterer for the Customer Satisfaction. http://www.researchgate.net

[29] https://www.megachicken.com.ng/order/ 